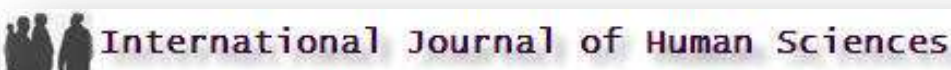

Volume: 12 Issue: 1 Year: 2015

\section{Bertolt Brecht in Latin America ${ }^{1}$}

\author{
Ebru Gökdağ ${ }^{2}$
}

\begin{abstract}
In 1943, when Bertolt Brecht and Kurt Weill's The Three Penny Opera opened in Mexico, Latin America encountered Brecht for the first time. Political concerns among Latin Americans, and their attempts to present them theatrically, pre-dated the widespread dissemination of Brecht's theories. After 1943, Brecht's work as a theoretician in Latin America had to wait another decade before it was to have influence there. Thus, when Latin America encountered Brecht, it was a case of parallel evolution rather than of direct influence. Brechtian theorizing and its influence on Augusto Boal's approach has been widely acknowledged. Some critics state that Boal extended ideas similar to Brecht's but improved upon them by transforming the audience from a reflective passive stance to an active participant. Yet Boal does more than merely extend or elaborate on the theories of Brecht. Brecht formulated his theory through critical and intellectual analysis, while Boal co-created his approach with individuals whom he was both teaching and learning from at the same time. Since Boal's work is based on four decades of practice, there is a commitment in his ideas that is far less intellectual and more practical, a passion in his devotion to transforming audience expectation and response that is wholly absent in Brechtian theorizing.
\end{abstract}

Keywords: Bertolt Brecht; Epic Theatre; Augusto Boal; Theatre of the Oppressed; Theatre in Latin America.

\section{Introduction}

The first time Latin America encountered Bertolt Brecht (1898-1956) was in 1943, when Brecht and Weill's The Three Penny Opera opened in Mexico. Brecht's work as a theoretician in Latin America, however, had to wait another decade before it was to have influence in Latin America. After the Berliner Ensemble's success in Paris with a production of Mother Courage during The Festival Of the Nations of 1954, Diana Taylor chronicled Brecht's entry into the Latin American theatrical consciousness. His influence spread after 1959 following the Communist revolution inCuba, and his theories, particularly because of their perceived scientific pedigree. During the 1960s, Latin American theatre practitioners translated, directed and performed Brecht's works from

\footnotetext{
1 "Brechtean Theorizing and Boalean Theorizing" Pedagogy and Theatre of the Oppressed Conference, 2004, Omaha, Nebraska, USA.

2 Assoc. Prof. Dr., Anadolu University, State Conservatory, Performing Arts Department, gokdage@gmail.com
} 
Gökdağ, E. (2015). Bertolt Brecht in Latin America. International Journal of Human Sciences, 12(1), 527-538. doi: $10.14687 /$ ijhs.v12i1.3103

Chile to Mexico. When Brecht's Kleines Organon fur das Theater (Short Organum for the Theatre) become available in the West during the 1960s, it too stimulated new ways of thinking about production and performance. The Colombian directors Santiago Garcia and Enrique Buenaventura staged noteworthy productions of Galileo in 1965 and The Seven Deadly Sins in 1969, while popular Columbian playwrights Enrique Buenaventura and Griselda Gambaro applied Brecht's epic structure to their plays, Documents from Hell (1968) and Information for Foreigners (1972). In both of these plays, Buenaventura and Gambaro emphasized the overtly political tendencies they had borrowed from Brechtian techniques, calling attention to what Taylor called the political oppression and "violence in their countries."

Brecht's theories tended to provide reinforcement of and motivation for the directions on which Latin American theatre practice had by the 1950s already begun to embark. Brecht had advocated theatre as an instrument of change in social and political structures, and several Latin American theatres accepted his advocacy without hesitation. Brecht's influence reached Brazil in 1945 with a successful production of Fear and Misery in the Third Reich in São Paulo making a deep impression on several Brazilian theatre groups, including the CPC (Centro Popular de Cultura), Oficina, and Arena. The Brazilian playwright Guarinieri initially rejected Brecht, but gradually came to accept several of Brecht's ideas “as work proposals, as well as a means to arouse political awareness as a theatre worker and as a thinker.”4 After Brecht became established with a large government subsidy in East Berlin in 1949, some Brazilian theatre artists began visiting East Germany on a regular basis. Those visits were not without consequence, as evidenced by the military junta's ban on travel to East Germany in 1968. In some ways, Brecht's techniques helped artists like Guarnieri to maintain hope that Brazilian theatre had been "internationalized" enough for appeals to the outside world to have some resonance and even evoke some response to the suppression Brazilian theatre artists were enduring under the junta.

This was the time of a dramaturgy that matured into an International Theatre of the Occasion dictated by the need for an immediate response. Stage language became more important than the making of new styles: ways had to be found around censorship. Theatre developed in response to the police but suffered severe limitations because everyone had to use allusions and metaphors. These were times of silence -- or shouts -- and sometimes uncontrolled, impatient whispers. ${ }^{5}$

\footnotetext{
3Diana Taylor, "Brecht and Latin America's: Theatre of Revolution." Brecht Sourcebook. Edited by Carol Martin and Henry Bial. (New York: Routledge, 1999), 172.

${ }^{4}$ Fernando Peixoto. "Brazilian Theatre and National Identity." The Drama Review (1990): 66.

${ }^{5}$ Fernando Peixoto. "Brazilian Theatre and National Identity." The Drama Review (1990): 66.
} 
Gökdağ, E. (2015). Bertolt Brecht in Latin America. International Journal of Human Sciences, 12(1), 527-538. doi: $10.14687 /$ ijhs.v12i1.3103

Leftist theatre groups in particular found Brecht's theoretical writings especially appealing. The "Nuevo Teatro" movement found in Brecht a kind of ideological compatriot. Even before Brecht's appearance in the artistic consciousness among Latin American theatre artists, Latin American stages were exposing injustices, violence, and repressions by combining testimony, story, history, fable, fiction, song, poetry and dance together with their traditional theatrical practice. A Cuban scholar named Rosa Ileana Boudet, described revolutionary theatre she had witnessed as "utilitarian" in terms of both educating the public and incorporating public participation in bringing solutions to various problems, whether social, political, cultural or economic. Boudet states "Theatre is an excellent vehicle to detect and combat problems." In the 1940s, a Cuban anthropologist named Fernando Ortiz witnessed a "tripartite" process in theatre that included "acculturation, deculturation and transculturation" through which the Cuban artists received and transformed material from other cultures such as Germany. Use of "tripartite" process helped prevent cultural imperialism. For example Orbitz state that transculturation "allow(ed) for creativity and selection in the process of cultural transmission." 8 Boal's approach to theatre as remediation for social and political injustice was therefore nothing unprecedented.

Of all the countries to embrace Brecht's ideas, and the use of theatre as a medium for political consciousness raising, Cuba was the most enthusiastic. That was especially true after the people's revolution in 1961, when groups like Conjunto Dramatico de Oriente and the Grupo Teatro Escambray moved away from scripted theatre and staged performances of participatory theatre. Some of the techniques these groups employed appear similar to Boal's methods, which he developed later. Diana Taylor cites one instance of the Cubans performing at the time of Cuban crisis in 1963, when

A group of actors meet on a corner and begin arguing about politics to the point of threatening physical violence; people gather around them and the group suddenly begins an improvised performance that deals with the most urgent political issues. Only midway through the performance does the crowd realize that it is attending a play. ${ }^{9}$

\footnotetext{
${ }^{6}$ M. Calvin M. Evenson. "Rethinking The Heroic: Demystification and Revision of History in the Nuevo Teatro." PhD diss., (U of Wisconsin -Madison, 1995) 77.

7 Diana Taylor, "Brecht and Latin America's: Theatre of Revolution." Brecht Sourcebook. Edited by Carol Martin and Henry Bial. (New York: Routledge, 1999), 173.

${ }^{8}$ Fernando Peixoto. "Brazilian Theatre and National Identity." The Drama Review (1990): 66.

9 Diana Taylor, "Brecht and Latin America's: Theatre of Revolution." Brecht Sourcebook. Edited by Carol Martin and Henry Bial. (New York: Routledge, 1999), 5.
} 
Gökdağ, E. (2015). Bertolt Brecht in Latin America. International Journal of Human Sciences, 12(1), 527-538. doi: $10.14687 /$ ijhs.v12i1.3103

Such experiments were apparently commonplace in Cuba, along with other experiments with new theatre practices that abandoned the script and encouraged audience involvement. The goal, obviously, was to stimulate political consciousness and motivate the capacity to take action, encouraging an "attitude of criticism which tries to awaken the audience"10 as Brecht had articulated in 1952. It is important to note, however, that political concerns among Latin Americans, and their attempts to present them theatrically, pre-dated the widespread dissemination of Brecht's theories. When Latin America encountered Brecht, it was a case of parallel evolution rather than of direct influence. Political theatre groups like Yuyachkani in Peru did acknowledge their debt to Brecht, using epic theatre techniques to train their actors in the 1970s. Most others, however, had begun to depart from traditional practices, incorporating collectivist approaches that rejected dependency on a playwright's scripts. Most of the Nuevo Teatro troupes in Latin America likewise provided free performances for their audiences and encouraged audience participation in their performances. Unlike Brecht, who worked only with professional actors, Nuevo Teatro troupes used mostly amateurs in their presentations and toured communities with little or no previous access to theatre.

Brecht's precedent of successfully combining politics with the aesthetics of theatre inspired leftist Latin American theatre artists. They realized, of course, that Brecht's economic situation was vastly different from their own. He enjoyed an enormous subsidy from the East German government for all his activities, but his preference for modest spectacle, unlike Piscator's earlier model of "epic theatre," had an enormous appeal for Nuevo Theatro practitioners. They were chronically underfinanced, not only because they received no subsidy, but also because the kind of work they did focused on audiences who were themselves without financial advantages. Thus the challenges of theatre practice Brecht had to face were often completely different from those which Latin American directors encountered. Yet they found in Brecht an ideological confederate, whose commitment to social and political transformation superseded the vast financial and institutional differences between them. His approach not to interpret existing systems but to change them was what Nuevo Teatro found most important. In his notes to Erwin Strittmatter's play Katzgraben, Brecht asserts that theatre should urge the audience to transform the world with critical knowledge. To accomplish that transformation, theatre practitioners "must infect a working-class audience."11 Latin American Nuevo Teatro practice liked the idea of "infecting" their audiences, because an

\footnotetext{
${ }^{10}$ Willet, John, trans. and eds. "Brecht on Theatre: Development of an Aesthetic." (New York: Hill \& Wang, 1957), 227.

${ }^{11}$ Evenson, M. Calvin. "Rethinking The Heroic: Demystification and Revision of History in the Nuevo Teatro." PhD diss., (U of Wisconsin -Madison, 1995), 80.
} 
Gökdağ, E. (2015). Bertolt Brecht in Latin America. International Journal of Human Sciences, 12(1), 527-538. doi: $10.14687 /$ ijhs.v12i1.3103

infection is conspiratorial and more difficult to suppress than an obvious malady. Some Latin American theatre practitioners initially tried to implement the more obvious of Brecht's epic theatre techniques and to follow his ideology strictly. They soon discovered that any successes they might initially have would ultimately be provisional. Without generous governmental subsidy, Brecht's theatre practice was an unrealistic proposal. It was also dangerous; police in most Latin American countries had authority to shut down any theatre performance they deemed subversive or objectionable. On an intellectual level, however, Brecht's ability to infuse "the epic form with Marxist ideology" provided Latin American artists with "one more way of framing and making sense of Latin America's revolutionary praxis and aspirations." Furthermore, as Diana Taylor has noted, "Brecht's efforts to combine anti-capitalist ideology with aesthetic principles"12 motivated Latin Americans to continue in their efforts to challenge capitalist ideology, but in ways best suited to their own Latin American context. For example, the Yuyachkani troupe of Peru realized that Brecht's nostrums were incompatible with the reality they and their audiences confronted, because Brecht's audiences differed so substantially. Brecht presented his audiences with characters as hapless objects of economic forces well beyond their control; he knew his audiences would perceive his characters' actions within a Marxist context. The Yuyachkani troupe enjoyed no similar, retroactively shared intellectual context like Marxism with their audiences. Their principal task was to get their audiences to perceive their present situation critically and take action to transform that situation. The struggles those audiences faced were ethnic, religious, racial, and gender-related. In addition to those problems, most audiences faced a brutalizing poverty. Such audiences were often comprised of indigenous and mestizo peoples who resided

on the margins of a capitalist society for various reasons--including linguistic, epistemic, cultural, and religious--not reducible (though bound into) economic discrepancies in power. The lack of reciprocity threatened to place them in positions of moral superiority reminiscent of political pamphleteers or religious proselytizers. $^{13}$

In order to approach their audiences, troupes like the Yuyachkani began studying various languages, cultures, music, dances, songs, and other performance codes imbedded in indigenous communities. In one instance, Yuyachkani troupe members invited residents from various indigenous communities to join their theatre group and teach them. They studied various languages

\footnotetext{
12 Diana Taylor, “Brecht and Latin America's: Theatre of Revolution.” Brecht Sourcebook. Edited by Carol Martin and Henry Bial. (New York: Routledge, 1999), 173.

${ }^{13}$ Diana Taylor, "Brecht and Latin America's: Theatre of Revolution." Brecht Sourcebook. Edited by Carol Martin and Henry Bial. (New York: Routledge, 1999), 177.
} 
Gökdağ, E. (2015). Bertolt Brecht in Latin America. International Journal of Human Sciences, 12(1), 527-538. doi: $10.14687 /$ ijhs.v12i1.3103

and learned the folklore of various communities in the Andes. In such efforts, implementing Brecht's methods were irrelevant. Like Brecht, they borrowed from non-Western approaches and were agreeable to experimentation. Some of these approaches and experiments became known to other leftist theatre troupes.

Some of those troupes were in Brazil. According to Fernando Peixoto, the director of theatre at the Brazilian Ministry of Culture's National Institute of Scenic Arts, imperialism and later capitalism had wounded Brazil, whose history required revolutionary liberation. In the twentieth century, Brazilian culture found itself torn between its indigenous values and the values, which colonizers and occupiers had imposed on her. Brazilian theatre reflected that dialectical conflict, according Peixoto,

The Portuguese armed with weapons and the cross "discovered" us -- our theatre owes its origins to efforts made by Jesuits to incorporate indigenous rituals into Iberian medieval auto sacramentale. The passage from religious to secular theatre was due to our imitation of the Portuguese, Spanish, and even French theatres. ${ }^{14}$

The twentieth century saw Brazilian theatre begin a slow progress towards finding its own identity. That progress began with successful musicals imitating French models, although immigrant workers in São Paulo did stagings in the 1920s based on Spanish and Italian anarchist movements-but those stagings were following European dramaturgical models. In 1922, Brazil's Communist Party was established, but its Marxist philosophy did not affect Brazilian theatre for many years. The establishment of Teatro de Brinquedo (Toy Theater) in 1927, an organization that continued until 1948, started a new phase in Brazilian theatre. At that time the Getúlio Vargas dictatorship dominated Brazil; it was a regime calling itself the "New State," one in which American imperialism replaced British imperialism. In 1932, the Toy Theatre's production of Joracy Camargo's Deus lhe Paque (May the Lord Reward You) of addressed Brazilian social problems, but the Toy Theatre's most significant contribution was the development of an indigenous dramaturgy, utilizing political themes, anti-imperialist sentiments, and nationalism as its subject matter. Oswald de Andrade's O Rêi da Vela (The King of the Candle, 1933), O Homem e o Cavalo (The Man and the Horse, 1934) and A Morta (The Dead Woman, 1937) were significant because their author was Brazilian, writing in Portugese, yet "seemed to be born of Meyerhold's or Brecht's theories (though it was not), with a political sarcasm worthy of Mayakovsky." 15

\footnotetext{
${ }^{14}$ Fernando Peixoto. "Brazilian Theatre and National Identity." The Drama Review (1990): 60.
}

${ }^{15}$ Fernando Peixoto. "Brazilian Theatre and National Identity." The Drama Review (1990): 62. 
Gökdağ, E. (2015). Bertolt Brecht in Latin America. International Journal of Human Sciences, 12(1), 527-538. doi: $10.14687 /$ ijhs.v12i1.3103

The emphasis on Brazilian subject matter, along with novel performance styles stimulated the establishment of Teatro do Estudante do Brasil (Brazilian Students' Theatre) in 1938, a development later followed by Grupo Experimental de Teatro (Experimental Theatre Group) and Grupo Universitario de Teatro (University Theatre Group). Both were amateur groups who experimented with various performance styles and social contexts. Teatro do Estudante do Brasil, established by Pascoal Carlos Magno presented Plinio Marcos's banned plays such as Barella (Gang Bang). Elzbieta Szoka states that Marco's plays "represent the best of what is known at the time as the "poetics of the oppressed." 16 With the onset World War II, Brazilian theatre hosted many foreign directors, for example Polish director Zbigniew Ziembinsky, whose expressionistic productions found appeal among audiences who were curious about European developments beyond the practices prevalent in Portuguese, Spanish, or French. Brazilian Theatre began its modern period after World War II concluded, and amongst its most prominent influences were those of many Italian directors such as Franco Zampari, Adolfo Celi, Luciano Salce and Flamínio Bollini Cerri. In 1948, with the world once again at peace, Teatro Brasileiro Communista or TBC (Brazilian Communist Theatre) began to stage plays in Rio de Janieiro, followed by the Teatro Arena de São Paulo (The São Paulo Arena Theatre) and Teatro Oficina de São Paulo (São Paulo Workshop Theatre). While TBC concentrated its focus on middle-class audience expectations, many Brazilians began to question the power structure in their country. Indeed the Arena Theatre's founding in 1956 was dedicated to the use theatre as tool for political action. In many ways, the establishment of Arena Theatre marked a transformation of leadership in Brazilian theatre from Italian directors to young Brazilian directors. The Italian director and founder of the Paulist Student Theatre (1955), Ruggero Jacobbi wrote in 1960:

I am leaving satisfied because I see that those principles that I used to defend so many years ago have now become commonplace: the affirmation of realism against mystic delirium; the creation of a Brazilian dramaturgy as the indispensable component of theatre; the foundation of a national popular culture. It is the young Brazilians' job now to realize this program. Some of them are already doing it. Some do it seriously, others improvise. However, the historical process is the same. Don't be afraid of making mistakes. ${ }^{17}$

When Augusto Boal became active in the Arena Theatre, he initiated a process of establishing a socialist theatre in act as well as thought, a theatre in which the actors, directors, and playwrights

\footnotetext{
${ }^{16}$ Szoka, Elizabeth. “The Spirit of Revolution in Contemporary Brazilian Theatre.” The Drama Review (1990): 71.

${ }^{17}$ Fernando Peixoto. "Brazilian Theatre and National Identity." The Drama Review (1990): 64.
} 
Gökdağ, E. (2015). Bertolt Brecht in Latin America. International Journal of Human Sciences, 12(1), 527-538. doi: $10.14687 /$ ijhs.v12i1.3103

risked their jobs and lives. This developed through many phases discussed in the first chapter of this dissertation. The poetics of this theatre initially influenced by theories of Stanislavsky, Grotowsky, Artaud, Kazan-Strasberg, Brecht, Freire and Aristotle. In borrowing as he did, Boal resembled Brecht, who borrowed extensively to create his "Brechtian" theatre. As he noted in his diary in 1929, a person "must stuff his pockets with them (theories) as if they were newspapers, always the latest, one can live nicely among theories, one can be snugly housed among theories. If one is to get on, one needs to know that there are lots of theories." Nobody, according to Daniel Gerold in his Theatre, Theory, Theatre, had "his pockets better stuffed" 18 with theories than did Brecht. Gerold writes that Brecht "wished to make available to the world at large the conclusions he had drawn from a 'scientific' study of his own stage practice as well as of the drama and theatre of all times." ${ }^{\prime 19}$ The scientific study Brecht claims to practice is about mechanism, reasoning, and social analysis, by applying "science of society," by which Brecht meant Marxist analysis. Through this analysis Brecht hoped to get his audience critically responsive to the world presented in his plays and ready to take action when they left the theatre, prepared with a changed attitude to transform the social structure. To have his audience respond, Brecht said that any theatrical intent should be to present in a form of theatre exposing the real contradictions from the fragments of reality, and that this reality should be open to change. He insisted on techniques such as Verfremdung, which distanced the audience from the action. Such techniques dissuaded the audience from the empathy expected in traditional dramatic presentations. They would instead be impelled to observe and judge the contradictions presented on the stage and take a critical attitude towards the proceedings.

Brecht employed the term "epic" as the title of his theory, a term with literary antecedents in use predating Brecht by several centuries. He used the term to emphasize specific features of his dramaturgy that opposed traditional Aristotelian dramatic structure. While the audience was involved with the situation of the character through empathy in Aristotelian theatre, for example, Brecht sought to turn his spectators into critical observers, thus hopefully increasing their capacity for subsequent action on their own. While the traditional theatre seduces them with empty emotions, Brechtian theatre asks his audience to make decisions. In the former, a man is essentially unchanged, whereas in Brecht he is brought to change and, indeed, enabled to change. At the core of the dialectic between Aristotelian and Brechtian hypotheses is traditional theatre's encouragement through empathy of passivity in the audience, assuming that spectators accept the

\footnotetext{
18 Gerould, Daniel, ed., Theatre, Theory, Theatre: The Major Critical Texts from Aristotle and Zeami to Soyinka and Havel. (New York: Applause, 2000), 11.

${ }^{19}$ Gerould, Daniel, ed., Theatre, Theory, Theatre: The Major Critical Texts from Aristotle and Zeami to Soyinka and Havel. (New York: Applause, 2000), 14.
} 
Gökdağ, E. (2015). Bertolt Brecht in Latin America. International Journal of Human Sciences, 12(1), 527-538. doi: $10.14687 /$ ijhs.v12i1.3103

world, as it is, as unalterable. The two main mechanisms fueling this are catharsis and empathy. In the latter one, spectators completely identify with the main character-to the point of having the feelings of the main character, and central to the former process is the climactic scene, a scene intended to purge the audience of pity and fear or of something. Some would say using pity and fear purging us of other feelings, such as in Boal's estimation, the desire to change a world that would bring inevitable destruction. Brecht sought alternatives to such "traditional" dramatic structures by insisting that his performers not turn into their characters and identify with them, but rather present them for inspection and contemplation. Doing so would bring the audience to observe the character objectively and, by insisting that the play should have an open ending instead of a cathartic climax, the play would incite audiences to complete the play through their own actions out in the world at large. Thus, the end of the play would be found in the lives of its audience, and the audience would become the true center of the play. It was as if by rejecting passive acceptance of the situation illustrated in the play the spectators accepted recruitment as members of a legion commissioned to go out into the world and complete the play in terms of the social and political vision informing it. Brecht wanted his epic theatre to unmask the widespread accepted view of social and political conditions and help the masses escape being the passive objects of history and lead them to become the active subjects of history. Brecht believed that the sole goal of revolutionary art was to motivate active participation in the world towards an attack on the social, political, and economic status quo. That attack was to begin during the performance. While the audience perceives the disorienting views of the world offered to them, it is at the same time being inculcated with solutions necessary to bring about a reorientation that would allow them, through subsequent action, to remake the world around them and remove the contradictions confronting them.

Rejecting passivity was the first step in epic theatre, but only the first step. The intention remains incomplete, because though now the audience has been brought, through critical thought, to understand the relations between the economic base and the superstructure of the social formation exposed in the play, there remains no infallible mechanism to lead the audience from the theatre and into the streets. The problems of society have been exposed, and the solutions proposed, or implied or asked for, but the means leading from the first to the second have not been forthcoming beyond perhaps, the rather vague notion of "revolution." While Brecht reveals the rot of society and envisions its resurrection, the one variable in his formula over which he has no control eluded him both theoretically and practically. The audience itself was that variable. Brecht had no way to insure that the audience will be inspired to leave the theatre literally or figuratively to take up arms against the status quo. The reason might be that Brecht's staged analyses of social condition, his 
Gökdağ, E. (2015). Bertolt Brecht in Latin America. International Journal of Human Sciences, 12(1), 527-538. doi: $10.14687 /$ ijhs.v12i1.3103

avoidance of presenting characters whose function is to stimulate critical thinking among the audience simultaneously and inevitably avoids the very thing needed to inspire the audience, namely emotion. Brecht's method is quite simply too intellectual and too rational. Those in full rational control of themselves rarely mount the street barricades. The result is an unavoidable conclusion that certain prominent elements of epic theatre were doomed. At the core of this failure is the basic fact that Brecht's dramaturgy, while radical in theory, was really not that radical in practice. It neither inspired nor enabled the audience to take the kind of revolutionary action for which the presentation called. As John Willet notes,

Verfremdung... is a matter of detachment, of reorientation: exactly what Shelley meant when he wrote that poetry "makes familiar objects to be as if they were not familiar," or Schopenhauer when he claimed that art must show "common objects of experience in a light that is at once clear and unfamiliar." The value of this conception for Brecht was that it offered a new way of judging and explaining those means of achieving critical detachment, which he had hitherto called "epic." It did not, so far as an outsider can see, lead him to change those means or introduce new ones, or even to make the overdue distinction between them and "epic" narration proper; for Verfremdung and Episierung seem to have been used by him to mean exactly the same thing. But it gave a rational basis to conclusion at which he had already arrived. ${ }^{20}$

Brecht's theatre audiences were primarily composed of intellectuals, politicians, and social theoreticians. His theatre was rarely more than a presentation to the already converted. His theories were conceived not in the give-and-take of everyday theatrical practice but in the rarefied atmosphere of one who sets before him a problem conceived on paper and resolved on paper. Brecht with his theories achieved to ask the questions that has been instrumental in slowly dismantling bourgeois theatre but, unfortunately when his theories actually placed before what should be ideal audiences, it fell flat. One reason for this could be that Brecht failed to take as his raw material the actual experience of those in the audience. Had he done so, his theories in fact, might have come to resemble those which Boal ultimately articulated.

Brecht's attachment to Marxism limited his direct contact with the very people he sought most to convince. As a Marxist tied to an ideology, Brecht was unable to adapt his dramaturgy to the realities of both theatrical practice and human nature, those very elements which so many

${ }^{20}$ Willet, John. “The Theatre of Bertold Brecht.” (New York: New Directions Press, 1968), 177. 
Gökdağ, E. (2015). Bertolt Brecht in Latin America. International Journal of Human Sciences, 12(1), 527-538. doi: $10.14687 /$ ijhs.v12i1.3103

academics saw as "novel" in his work, but were in many ways a reworking of already standard practice. The actor Sam Wanamaker witnessed Helene Weigel'a performance in Mother Courage and claimed it was "indistinguishable from a superb Stanislavsky-trained actress;" critic Paul Rilla also saw Brecht's production of Mother Courage and said it "has no more epic elements than a Shakespearean history." 21 On one hand, like these and other cases, Brecht lived in contradiction. Brecht requested his audience to take an active role in the social struggle, but failed to compel it. On the other hand however, Brecht distrusted very much the use of emotion to compel, because he saw what it led to. He was looking for thinking actors, a thinking theatre. That is not entirely a contradiction. Brecht preached Marxism, but in the "elite" world of theatre in which he functioned he would not (or could not) practice it himself.

Brecht had a history of avoiding the kind of action he advocated. In 1936, for example, he had an opportunity to assume an active role in fighting alongside communists in the Spanish civil war, but he preferred staying in the friendlier confines of Denmark. Irving Fetscher says that Brecht's reason for not joining in the conflict was that "with a pen he could be of more use than with a machine gun." 22 Brecht may not have been a coward, but he exposed himself to charges of having violated a Marxist concept of division of labor. In class societies, labor is divided into physical and mental work. Marxists advocated the elimination of such artificial labor divisions as one of their primary goals, both in the arts and in any other field. As Dave Laing stated, "In a communist society there are no painters, but at most people who engage in painting among other activities." ${ }^{23}$ Brecht upheld that division by claiming a specialization. He divided revolutionary activity between physically "holding the gun" and intellectually "holding the pen." His stance was thoroughly bourgeois and class-oriented, opposed to a central tenet of the Marxist philosophy he so ardently espoused. His contradictory posture was analogous to the vagaries of the "epic theatre," one reason there are few instances in which Brecht successfully instigated political or social transformation. Boal, on the other hand, extended ideas similar to Brecht's but improved upon them by "transforming the spectator from a reflective stance to an active one." ${ }^{24}$

Yet Boal does more than merely extend or elaborate on the theories of Brecht. Since Boal's work is based on four decades of practice, there is a commitment in his ideas that is far less intellectual and

\footnotetext{
${ }^{21}$ Willet, John. “The Theatre of Bertold Brecht.” (New York: New Directions Press, 1968), 184.

${ }^{22}$ Fetscher, Irvin, introduction to Bertolt Brecht: Political Theory and Literary Practice, edited by Weber Betty Nance and Hubert Heinen, (Athens: U of Georgia Press, 1980), 16.

${ }^{23}$ Laing, Dave. “The Marxist Theory of Art: An Introductory Survey.” (Colorado: Westview P, 1986), 7.

${ }^{24}$ Alicia Santos, qtd in Edgar Quiles. "The Theatre of Augusto Boal.” PhD diss., (Michigan State U of Ann Arbor-MI, 1981), 21-22.
} 
Gökdağ, E. (2015). Bertolt Brecht in Latin America. International Journal of Human Sciences, 12(1), 527-538. doi: $10.14687 /$ ijhs.v12i1.3103

more practical, a passion in his devotion to transforming audience expectation and response that is wholly absent in Brechtian theoring. Brecht is Greman afterall, and Boal is Latin American. Boal is thus more than a latter-day Brechtian. Brecht's reputation among historians and theorists benefited from his well-established canon of fully scripted plays; Boal's legacy tends to consist of very sketchy instructions intended to assist the performance of his plays. Boal also disappoints many Marxists because his aesthetic system is devoted to the process of adaptation and taking new shape where conditions require. Boal's practice, ideas, and body of work has emerged from the practice, day after day, month after month, year after year, of a man wholly committed to a theatre free from elitist constraints. His work offers none of the commercial advantages theatre professionals have enjoyed over the decades, profiting enormously from the thoroughly capitalist appeal Brecht presents to producers, directors, recording artists, publishers, and other members of a distinctly non-Marxist elite thus the continued use of Brecht's plays in privileged regional theatres. Boal in many ways deprives such elites of their traditional power, breaks down walls between audience and actor and transforms the stage into a rehearsal area for revolution. Brecht formulated his theory through critical and intellectual analysis, while Boal co-created his approach with individuals whom he was both teaching and learning from at the same time. Thus Boal's theories are a demonstration of a result of a lived practice.

\section{Works Consulted}

Evenson, M. Calvin. "Rethinking The Heroic: Demystification and Revision of History in the Nuevo Teatro.” PhD diss., U of Wisconsin -Madison, 1995.

Fetscher, Irvin, introduction to Bertolt Brecht: Political Theory and Literary Practice, edited by Weber Betty Nance and Hubert Heinen, Athens: U of Georgia Press, 1980.

Gerould, Daniel, ed., Theatre, Theory, Theatre: The Major Critical Texts from Aristotle and Zeami to Soyinka and Havel. New York: Applause, 2000.

Laing, Dave. “The Marxist Theory of Art: An Introductory Survey.” Colorado: Westview P, 1986.

Peixoto, Fernando. "Brazilian Theatre and National Identity." The Drama Review (1990): 60- 69.

Quiles, Edgar. "The Theatre of Augusto Boal." PhD diss., Michigan State U of Ann Arbor-MI, 1981.

Szoka, Elizabeth. "The Spirit of Revolution in Contemporary Brazilian Theatre." The Drama Review (1990): 70-83.

Taylor, Diana. "Brecht and Latin America's: Theatre of Revolution." Brecht Sourcebook. Edited by Carol Martin and Henry Bial. New York: Routledge, 1999.

Willet, John. “The Theatre of Bertold Brecht.” New York: New Directions Press, 1968.

Willet, John, trans. and eds. "Brecht on Theatre: Development of an Aesthetic.” New York: Hill \& Wang, 1957. 